\title{
The usefulness of bioelectrical body composition analysis (BIA) in the proper assessment of nutritional status in children and adolescents with idiopathic scoliosis (IS)
}

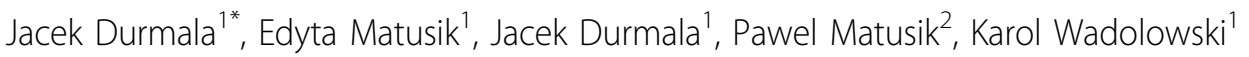 \\ From 10th International Conference on Conservative Management of Spinal Deformities - SOSORT 2013 \\ Annual Meeting \\ Chicago, IL, USA. 8-11 May 2013
}

\section{Background}

Based on our recent data, nutritional status disturbances (both under- and overweight) can be associated with the severity of scoliotic curve.

\section{Purpose}

The study objective was to compare two methods for the assessment of nutritional status (BMI vs. BIA-body composition analysis by bioelectrical impedance analyzer) in IS patients.

\section{Methods}

For a total of 317 IS patients (240 girls and 77 boys), mean age $14.11 \pm 2.79 y$, the scoliotic curve was assessed by Cobbs angle and angle vertebra rotation (AVR). Height, weight, waist and hip circumferences were measured and BMI, BMI Z-score, waist/height ratio (WHtR) and waist/ hip ratio (WHR) were calculated for the entire group. Body composition parameters, such as fat mass (FAT), fat-free mass (FMM), predicted muscle mass (PMM) and total body water (TBW), were evaluated using a bioelectrical impedance analyzer. Nutritional status was classified by centile charts for BMI as underweight, normal weight, overweight or obese, and for FAT\% as underfat, lean, overfat or adiposity. This was a prospective, randomized study.

\section{Results}

Nutritional status assessed by BMI has been associated with $21.1 \%$ of misclassification compared to BIA. There were important differences between the percentage of underweight vs. underfat patients (13.9\% vs. $9.5 \%)$, overweight vs. overfat ( $5.4 \%$ vs. $7.9 \%$ ) and obesity vs. adiposity ( $2.8 \%$ vs. $5.0 \%)$. There was no significant correlation between BMI and scoliosis severity in the subgroups classified by standard measurement. However, the BMI Z-score correlated significantly with Cobb and AVR in every BMI-classified subgroup. There were also significant correlations between body composition parameters (BIA) and vertebral deformity in only the normal BMI group. After the correction to the FAT\%, 252 (78.9\%) children were properly classified; of this group of IS patients, statistical analysis showed strong $(\mathrm{p}<0.001)$, significant correlation between either Cobb's angle or AVR vs. every (standard and bioelectrical) anthropometrical parameter.

\section{Conclusions and discussion}

Nutritional status classification by BMI assessment overestimates the underweight and leads to the underestimation of both overweight and obese patients with IS. Bioelectrical impedance analysis is a useful tool for the proper nutritional status assessment in the pediatric population with IS. Properly assessed nutritional status is significantly associated with the severity of scoliotic curve assessed by Cobb's angle and AVR.

\footnotetext{
* Correspondence: jdurmala@gmail.com

'Department of Rehabilitation, Medical University of Silesia, Katowice, Poland Full list of author information is available at the end of the article
} 


\section{Authors' details}

'Department of Rehabilitation, Medical University of Silesia, Katowice, Poland.

${ }^{2}$ Department of Pediatrics, Pediatric Endocrinology and Diabetes, Medical

University of Silesia, Katowice, Poland.

Published: 18 September 2013

\section{References}

1. Matusik E, Durmala J, Matusik P, Piotrowski P: Evaluation of nutritional status of children and adolescents with idiopathic scoliosis: a pilot study. Ortop Traumatol Rehabil 2012, 14:351-362.

2. Grivas TB, Arvaniti A, Maziotou C, Manesioti MM, Ferqadi A: Comparison of body weight and height between normal and scoliotic children. Stud Health Technol Inform 2002, 91:47-53.

3. McCarthy HD, Cole TJ, Fry T, Jebb SA, Prentice AM: Body fat reference curves for children. Int J Obes 2006, 30:598-602.

doi:10.1186/1748-7161-8-S2-035

Cite this article as: Durmala et al:: The usefulness of bioelectrical body composition analysis (BIA) in the proper assessment of nutritional status in children and adolescents with idiopathic scoliosis (IS). Scoliosis 2013 8(Suppl 2):O35.

\section{Submit your next manuscript to BioMed Central} and take full advantage of:

- Convenient online submission

- Thorough peer review

- No space constraints or color figure charges

- Immediate publication on acceptance

- Inclusion in PubMed, CAS, Scopus and Google Scholar

- Research which is freely available for redistribution

Submit your manuscript at www.biomedcentral.com/submit
C Biomed Central 